\title{
Reaching out to the community
}

\author{
Models that work
}

\author{
by Julie Todaro
}

$\mathrm{C}$ oncern for community, collaboration, and partnership in higher education is not new. Higher learning environments have been working with and within their neighborhoods and communities for decades. Goals and results (exclusive of the education-driven programs, such as research consortia, internships, etc.) have varied, but programs typically on-campus over the years have included:

- admissions criteria, curriculum design, and scheduling designed to meet the needs of the community member or "non-traditional" student;

- campus resources opened up for the public, such as fine arts productions, art exhibits, and sports, food, and recreational facilities made available for community use;

- special programs, such as enrichment classes for alumni and retirees and camps for children; and,

- special use of expert staff and resources, such as unique hospital programs (testing, diagnosis, and critical care) and use and borrowing privileges for campus libraries either in general or limited to certain times or certain days.

Students, faculty, and staff have also reached out into community life.

- Student social and service groups adopt neighborhood projects.
- Student groups, such as athletic or theater groups, perform off campus for entertainment or fundraising.

- Faculty members guest lecture for community groups and often work with local service groups on a consulting basis.

These projects and programs are both altruist and good business. Colleges and universities have long seen the benefits of forging strong relationships with their alumni but there are also great rewards from "doing good." Strong ties result in strong recruitment, support from the business community, "pro" votes during any community vote needed, and enriched resources, collections, and research possibilities.

\section{The old and the new}

Because some or many of these projects and programs exist in higher education environments today, the new or revolutionary ideas of collaboration or partnerships may easily be dismissed or overlooked because the feeling may be that "we're doing that."

The reality is that there are so many more possibilities where relationships can be designed to increase student research and learning, to enrich teaching, to attract a new generation of students, to interest older or returning students to retrain or retool, to become eligible for outside/in- 


\section{To embrace newer collaborations}

or partnerships is not a matter of excluding or discontinuing existing ones. In fact, many of the newer projects and programs are expansions or enhancements of those in progress.

creased funding, and to enrich the life of the community and the campus in general. ${ }^{1}$

To embrace newer collaborations or partnerships is not a matter of excluding or discontinuing existing ones. In fact, many of the newer projects and programs are expansions or enhancements of those in progress. Instead, colleges and universities and community partners should look at the differences or the shifts between the old and the new.

Typically older projects and programs concentrate on expanded access to the campus and campus resources and activities, additional but similar work for existing staff, bringing existing programs and curriculum to new audiences, more short-term and sporadic activity, and little or no specific commitments of dedicated dollars

New collaborations and partnerships, while including older methods, also can mean research into identifying the needs of audiences, possibly serving new constituents, investigating and implementing new ideas/curricula to meet specific identified needs, and often working differently or with groups instead of just working or doing for new groups. In addition, new projects and programs can mean economic and efficient use of existing dollars, attracting outside dollars reserved for collaborations and partnerships, and line item and targeted budgeting for an ongoing commitment of dollars.

The following examples are primarily library and information-related. ${ }^{2}$ Although the underlying theme of many of the examples listed here includes information literacy, many of the projects and programs ciearly go beyond the topic both in content and in benefits.

\section{Duke University-Durham Public Schools}

This program, funded by AT\&T, is designed to match technology mentors from the university library staff with public school teachers, offering both formal classes for teachers with one-on-one mentor sessions in the use of educational technology.

\section{University of California Berkeley- Oakland and San Francisco Unified School Districts}

The goal of this project, funded by Department of Commerce-TIIAP Grant, is to bring Internet technology to $\mathrm{K}-12$ schools in the Bay area. The current library grant covers development of sample lesson plans based on the California Heritage Collection, a digital library of archival resources on California history, and work within the schools to promote the integration of the Internet and primary sources into the curriculum.

\section{University of Maine at Farmington}

This project provided 3 teacher in-service workshops and 20 sessions for area school children, grades 3-12. Completed as a formal collaboration with the local school district, it was funded through a Bell Atlantic Excellence in Education award. The grant project was written by the library director in collaboration with the area superintendent of schools.

\section{University of California Irvine}

The University of California Irvine (UCI) Libraries received a University of California School-University Partnership Program grant to establish a two-year pilot program that will lay the groundwork for long-term collaboration between the UCI Libraries and targeted Orange County high schools. The School Partnership for Instruction, Research, and Information Technology (SPIRIT) Program objectives are to develop partnerships to teach lifelong learning skills to high-school students and to help increase the number of students that meet and exceed UCI admissions requirements.

\section{Link 2 Learn Project (http://www.I2I. duq.edu/contact.html)}

Duquesne University, Gannon University, St. Vincent College, and other cooperating insti- 
tutions propose to address the development of the skills of information problem-solving, generally known as information literacy in the high-school population for librarians, teachers, and high-school students in the 21 cooperating schools in the Western Pennsylvania region.

These partners have or are in the process of identifying information problem-solving literacy prerequisite skills for high school teacher-librarians and developing appropriate professional development opportunities for these teacher-librarians to enable them to serve as catalysts and resources for the professional development of faculty in their schools.

The Link 2 Learn Web page states: "Including information literacy components into the curricula in all content areas is the longerterm goal of the project. To this end, literacy skill development workshops will be developed and provided, initially to the teacherlibrarians then through the teacher-librarians to teaching personnel in their buildings, and finally to students through the teaching personnel working closely with the teacher-librarians."

\section{Oregon State University}

Staff from the university, the public library, and local school district media specialists are working to establish and implement instructional guidelines for information literacy in the community at large.

\section{SUNY Oswego}

University librarians and school library administration and media specialists have established a formal arrangement in the university library. They have a representative who attends all School Library System Council meetings and acts as a liaison between the school libraries and the university library.

The librarians use this fairly close relationship with the school libraries and the high-school librarians to bring the classes in for instruction in the use of a college library.

\section{University of Cincinnati}

The university library has created a soft money position for $\mathrm{K}-12$ outreach in the Cincinnati community of schools.

\section{University of Michigan}

The university regularly holds workshops where high-school librarians visit the university libraries to look at existing resources to see what they could use in their work with students in area high schools. In addition, the Cultural Heritage Initiative for Community Outreach (CHICO) is based at the University of Michigan School of Information. CHICO includes participants from the School of Information, University departments in the arts and humanities, and area K-12 schools as well as local, regional, and national museums and public libraries. "The goal of CHICO is to make cultural heritage materials accessible to a broad array of audiences. Through our pilot projects with area partners, we are creating online multimedia resources with a strong multicultural focus, and are developing personalized services and programs to assist in the use of online technologies and resources. Our projects incorporate images, sound and video to enrich museum visits, classroom instruction, and independent research."3

\section{University of Nevada}

The Learning Resource Center (LRC) is housed in the College of Education at the University of Nevada. The LRC is staffed by three school district employees and three university employees. The Center was founded ten years ago to assist the students and professors of the university, while assisting the teachers and student teachers of Washoe County School District. The Center provides media services and resources, including instructional support and curriculum enrichment. Teachers and administrators in surrounding school districts are invited to use the center's resources as well as staff and faculty from private schools and other school districts.

\section{University of Washington}

The University of Washington has exciting plans for university $/ \mathrm{K}-12$ initiatives for the coming years. This initiative discusses the hands on teaching of children, technology partnerships through the TLT program, a brain and research center and a K-12 leadership initiative. ${ }^{4}$

Other general project and program collaboration and partnership ideas inclucle:

- Expanded use of conference and formal research forums for discussing partnerships and collaborations. 


\section{There is no one model that works}

for every group. Work is under-

way, however, to establish the

elements of existing successful

information literacy partnerships

and coilaborations...

- Design of virtual/digital environment for community members housed on college and university Web sites, such as small business help and curriculum pages.

- Design of community Web sites through work with instructional design classes and community freenets to offer local and small organization Web presence.

- Expanded internship/mentor roles be tween junior-high and high-school students and college and university staff in info-tech rich learning and teaching environments

- Expanded "show and tell" of learning environments between and among $\mathrm{K}-12$ and higher education, including visits of $\mathrm{K}-12$ faculty to colleges and universities and visits to $\mathrm{K}-12$ environments by college and university staff.

- Expanded multitype consortia for e-resources.

- Cooperative design of user education modules for both electronic consortia products and generally used print materials.

- Expanded formal networking of multitype library and information science professionals in communities (general, themerelated, or problem solving).

- Expanded use of existing of uniquely designed standards and guidelines for user education/information literacy in communities.

- Expanded use and standardization of linking education and community Web environments to aid users in easy transitions among and between resources and environments.

There is no one model that works for every group. Work is underway, however, to establish the elements of existing successful information literacy partnerships and collaborations that determine what elements must be present to ensure higher measures of success.

Although upcoming issues of CERL News will feature a number of columns highlighting unique and successful partnerships and collaborations, interested or active partners and collaborators should read and contribute to Nancy Kranich's Information Literacy Community Partnerships Initiative at http:// www.ala.org/kranich/literacy.html or to ALA Special Presidential Committee Information Literacy Community Partnerships Initiative at http://Irs.austin.cc.tx.us/staff/Inavarro/ CommunityPartnerships/Toolkit.html.

\section{Notes}

1. For additional benefits see Betsy Wilson, "Community and Collaboration: The Year Ahead," GERL Neus 61, no. 8 (September 2000): 698-701.

2. These examples were taken from the Examples of Partnerships Focused on Information Literacy section on ALA President Nancy Kranich's Wel) site (http://www.ala org/kranich/examples.html) and from the ALA Special Presidential Committee Community Partnerships Toolkit (http://Irs.austin.cc.tx.us/ staff/Inavarro/CommunityPartnerships/ Toolkit.html).

3. Visit the CHICO site at http://www si.umich.edu/CHICO/.

4. The University of Washington's initiatives is outlined by the UW President at http://www. Washington.edu/president/ articles/K-12speech.html).

5. For an example visit "Invitational Conference on $\mathrm{K}-12$ Outreach from University Science Departments" held in North Carolina in February 2000 at http://www.ncsu.edu/ science_house/InformationFolder/ BWconference.heml

("Academic librarians as advisors" continued from page 782)

first and foremost, educators who are skilled in listening, providing information, and working with students to accomplish their academic goals. These skills are extremely useful in advising students about choosing courses and career plans.

Being involved with students' lives and helping them make important life decisions is a very rewarding experience. Serving as an academic advisor gains the respect and admiration of a group of people who will always remember and appreciate the time taken by that one person who cared about them enough to help them plan for their future. 
